\title{
FATIGUE IN PATIENTS WITH AUTOIMMUNE THYROID DISEASES
}

Zorica Jovanovic ${ }^{1}$, Svetlana Miletic-Drakulic ${ }^{1,2}$, Gordana Toncevv ${ }^{1,2}$, Olgica Mihaljevic ${ }^{1}$, Svetlana Djukic ${ }^{1}$, Jasna Jevdjic ${ }^{1}$, Snezana Zivancevic-Simonovic ${ }^{1}$ ${ }^{1}$ Faculty of Medical Sciences, University of Kragujevac, Kragujevac, Serbia

${ }^{2}$ Clinic of Neurology, Clinical Centre Kragujevac, Kragujevac, Serbia

\author{
ZAMOR KOD PACIJENATA SA AUTOIMUNSKIM BOLESTIMA \\ ŠTITASTE ŽLEZDE

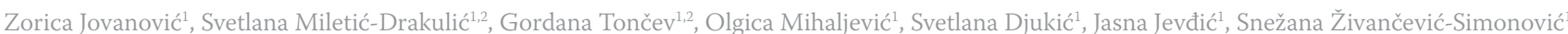 \\ ${ }^{1}$ Fakultet medicinskih nauka, Univerzitet u Kragujevcu, Kragujevac, Srbija \\ ${ }^{2}$ Klinika za neurologiju, Klinički centar Kragujevac, Kragujevac, Srbija
}

Received / Primljen: 08. 03. 2016.

Accepted / Prihvaćen: 24. 03. 2016.

\begin{abstract}
Fatigue is a common feature in a wide variety of chronic inflammatory and autoimmune diseases, but fatigue in autoimmune thyroid disease (AITD) has not been investigated so far. The aim of this study was to examine fatigue in patients with AITD and to analyse the correlation between fatigue and the serum concentrations of thyroid antibodies, thyroid function and depression. This cross-sectional clinical study included 62 patients with increased concentrations of thyroperoxidase antibodies (TPOAbs) as confirmation of AITD and 52 healthy individuals who were negative for thyroid antibodies; all controls were euthyroid. Thyroid antibodies, free thyroxine and thyroid-stimulating hormone were measured in the sera of all subjects. The Fatigue Severity Scale was used to measure the severity of fatigue; the level of depression was measured by the Beck Depression Inventory. Eight (12.9\%) patients had evident fatigue, 7 (11.3\%) patients had fatigue limit values, and 47 (75.8\%) patients had no fatigue. The frequency of fatigue was highly significant and almost three times higher in the AITD patients compared to the control group, in which only 2 (3.8\%) patients had evident fatigue. The majority of patients with fatigue had normal thyroid function, and only one (1.6\%) patient had overt hypothyroidism. Seven (11.3\%) patients had both fatigue and depression, whereas one $(1.6 \%)$ patient had fatigue without depression. We did not find significant correlations between fatigue and the concentrations of thyroid antibodies, but we found statistically significant correlations between fatigue and depression in AITD patients.
\end{abstract}

Keywords: antibodies, depression, fatigue, thyroid disease, thyroid function

\section{SAŽETAK}

Zamor je simptom koji prati mnoge hronične inflamatorne $i$ autoimunske bolesti, medutim, učestalost zamora kod osoba sa autoimunskim bolestima štitaste žlezde (engl. autoimmune thyroid disease, AITD) do sada nije ispitivana. Cilj ovog rada je da se ispita postojanje zamora kod osoba sa AITD $i$ da se analizira da li je težina zamora povezana sa serumskim koncentracijama anti-tireoidnih antitela, tireoidnom funkcijom i/ ili depresijom. Kod svih ispitanika izmerene su serumske koncentracije anti-tireoidnih autoantitela, slobodnog tiroksina $i$ tireostimulišućeg hormona. U eksperimentalnu grupu su uključena 62 pacijenta sa AITD i povećanom koncentracijom autoantitela specifičnih za tireoidnu peroksidazu (engl. thyroperoxidase antibodies, TPOAbs), a u kontrolnu grupu 52 eutireoidna ispitanika bez povećanih koncentracija TPOAbs. Za procenu stepena zamora korišćena je Skala težine zamora, a nivo depresije meren je primenom Beck-ove skale depresivnosti. Kod osam (12,9\%) pacijenata sa AITD utvrdeno je evidentno postojanje zamora, $7(11,3 \%)$ pacijenata sa AITD imalo je granične vrednosti, dok kod $47(75,8 \%)$ pacijenata sa AITD nije utvrdeno postojanje zamora. Zamor je skoro tri puta učestaliji kod pacijenata sa AITD u odnosu na kontrolnu grupu, u kojoj je zamor utvrden kod 2 (3,8\%) ispitanika. Kod većine pacijenata sa zamorom tireoidna funkcija je bila normalna, a samo jedan pacijent (1,6\%) imao je tešku hipotireozu. Kod sedam (11.3\%) pacijenata sa AITD zamor je bio udružen sa depresijom, a samo jedan (1,6\%) pacijent imao je zamor bez depresije. Korelacija izmedu stepena zamora $i$ koncentracije anti-tireoidnih antitela nije pokazana, dok statistički značajna korelacija između zamora i depresije kod pacijenata sa AITD postoji.

Ključne reči: antitela, depresija, zamor, bolesti štitaste žlezde, tireoidna funkcija 


\section{INTRODUCTION}

Fatigue is defined as an overwhelming sense of tiredness, a lack of energy and a feeling of exhaustion $(1,2)$. Fatigue is a common feature of a wide variety of diseases, including chronic inflammatory, infectious, neurological, and psychiatric diseases, and cancer $(2,3)$. The overall prevalence of chronic fatigue depends on the type of instrument used to measure fatigue (4). In many cases, fatigue is associated with inflammation, including both acute infectious and chronic inflammatory disorders. Fatigue is a common feature among patients with multiple sclerosis (5), rheumatoid arthritis (RA) (6), systemic lupus erythematodes (SLE) (7), primary Sjögren's syndrome (8) and autoimmune thrombocytopenia (9).

To our knowledge, this is the first study of fatigue in patients with autoimmune thyroid disease (AITD). The aim of this study is to investigate fatigue in patients with AITD and to determine whether there is a correlation between the symptoms of fatigue and the serum concentrations of thyroid antibodies (Abs) or with the thyroid function. Because depression is strongly associated with fatigue and thus may affect the measurement of fatigue as a confounding factor (2), an additional aim of this study is to examine the prevalence of depression in patients with AITD and to determine whether fatigue and depression in patients with AITD are associated.

\section{MATERIALS AND METHODS}

\section{Study population}

The research was conducted at the Centre of Nuclear Medicine and the Clinic of Neurology, Clinical Centre Kragujevac, in accordance with the Declaration of Helsinki (2000) of the World Medical Association. This study was approved by the Ethics Committee of the Clinical Centre Kragujevac.

The study included 62 patients who showed increased concentrations of thyroperoxidase antibodies (TPOAbs) as confirmation of AITD. After the finding of increased TPOAbs concentrations, patients were informed about the study protocol, and consent was obtained from each subject before they were included in further testing. The control group consisted of 52 healthy individuals who were negative for thyroid antibodies, and all controls were euthyroid.

\section{Methods}

The concentrations of thyroglobulin antibodies (TgAbs) and thyroid function (free thyroxine and thyrotropin) were evaluated in all study participants. All blood samples had been obtained originally for diagnostic purposes. Blood samples $(10 \mathrm{ml})$ from each subject were taken by venepuncture, and the serum was separated by centrifugation at $2000 \mathrm{rpm}$ for 15 minutes. The sera were divided into separate tubes for each analysis, stored frozen at $-20^{\circ} \mathrm{C}$, then thawed and assayed.

The concentration of TPOAbs was determined by a radioligand assay (TPO-Ab-CT, Cis-Biointernational, France) according to the manufacturer's instructions. The lower detection limit for this assay was $8 \mathrm{U} / \mathrm{ml}$. The measured TPOAb concentrations were analysed towards the value of $130 \mathrm{U} / \mathrm{ml}$, whereas autoantibody concentrations higher than $130 \mathrm{U} / \mathrm{mL}$ were considered "increased".

The concentration of $\mathrm{TgAb}$ was determined by a competitive "one-step" radioimmunoassay (TgAb I step, CisBiointernational, France). The method was calibrated against the WHO First International Reference Preparation CRM 65/93 and had an analytical detection limit of $6.0 \mathrm{IU} / \mathrm{ml}$. Autoantibody concentrations higher than 30 $\mathrm{IU} / \mathrm{mL}$ were considered "increased".

The concentration of free thyroxine (fT4) was determined by a radioimmunoassay (Cis-Biointernational, France). The detection limit for this assay was $0.5 \mathrm{pg} / \mathrm{ml}$, and the reference range was $7-18 \mathrm{pg} / \mathrm{ml}$.

The concentration of thyrotropin (TSH) was determined by an immunoradiometric assay (IRMA TSH, Zemun, Serbia), with a detection limit of $0.056 \mathrm{mIU} / \mathrm{L}$ and reference range of 0.3-5.5 mIU/L.

The Fatigue Severity Scale (FSS) (10), which focuses on the physical symptoms of fatigue, was used to assess the severity of fatigue. FSS contains a total of 9 questions, and all subjects rated their responses on the scale from 1 to 7 , where 1 represents disagreement and 7 represents complete agreement with the statement. The subjects were assigned to one of two groups on the basis of FSS scores. One group included patients with fatigue (F), which was identified by an FSS score of at least 5 , and the other group included patients without fatigue (WF), which was identified by an FSS score of 4 or less. Patients with FSS scores between 4.1 and 4.9 were classified in the marginal group. Patients in the marginal group were excluded from the between-group analyses, although their scores were included in the correlational analysis of fatigue severity. Patients diagnosed with chronic systemic connective tissue diseases, anaemia, tumours, liver disease or kidney disease were excluded from the study. Patients who had taken psychoactive medication (e.g., steroids, amantadine or antidepressants) in the previous two months that might have affected fatigue were also excluded.

Depression was diagnosed using the DSM-IV criteria for depressive symptoms (American 1994), and the level of depression was measured by using the Beck Depression Inventory (BDI) (12). This scale contains 21 questions that refer to the patient's mood in the last 4 weeks. The measured dimensions include cognitive, somatic and motivational aspects of depression.

\section{Statistical analysis}

The data were analysed using descriptive statistics, the Mann-Whitney test, Spearman correlation, the KruskalWallis test and binary logistic regression. Statistical sig- 


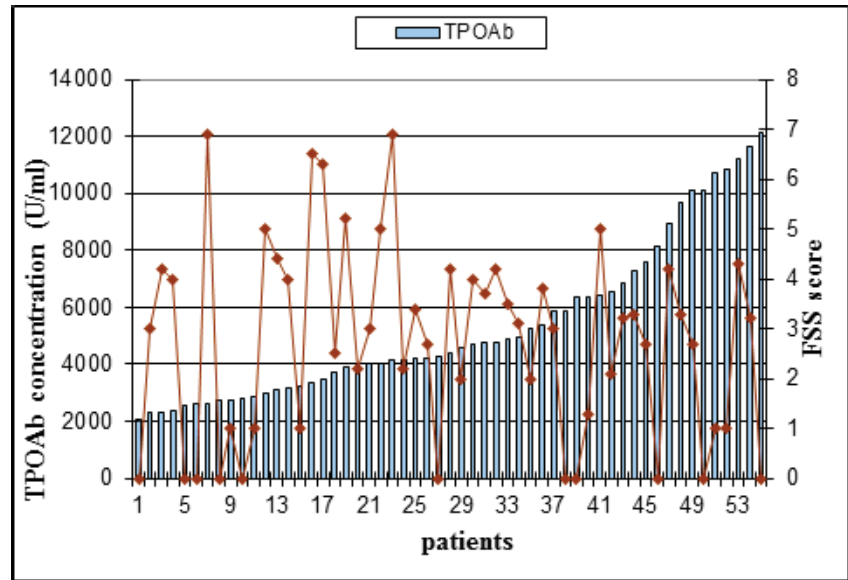

Figure 1. TPOAbs and fatigue in patients with AITD

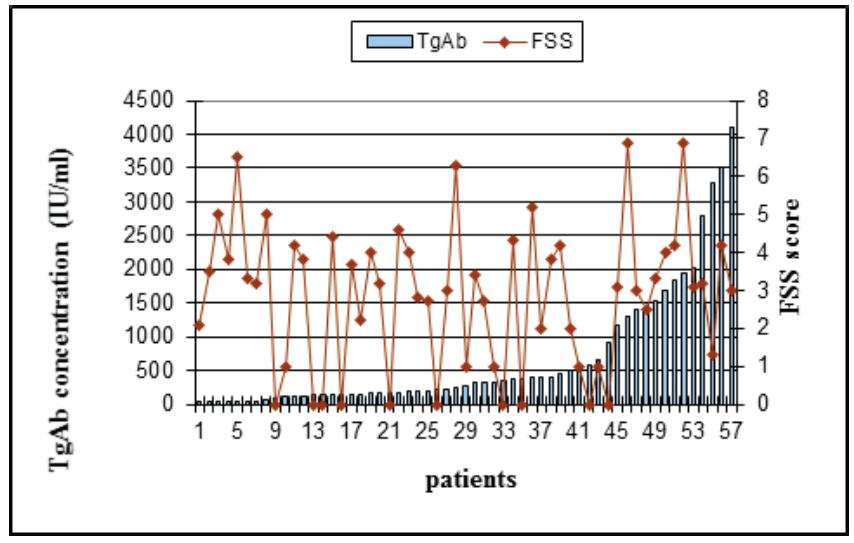

Figure 2. TgAbs and fatigue in patients with AITD

nificance was accepted when the probability (p) was less than or equal to 0.05. SPSS 10.0 and the Microsoft EXCEL programme were used for the analyses.

\section{RESULTS}

Fatigue and thyroid autoantibodies

The study included 62 patients (60 women, 96.8\%; 2 men, $3.2 \%$ ) with autoimmune thyroid disease. The mean age was 51.6 (SD 12.45) years. The youngest patient was 22 years old, and the eldest was 75 years old. All patients had increased serum concentrations of TPO antibodies, and the average value of TPOAb was 4891 (SD 2921) U/ $\mathrm{mL}$ (minimal concentration $280 \mathrm{U} / \mathrm{ml}$, maximum 12125 $\mathrm{U} / \mathrm{ml}$ ). The control group consisted of 52 healthy subjects without TPOAbs and TgAb (46 women, 88.5\%; 6 men, $11.5 \%$ ). The mean age was 45 (SD 10.46) years.

From a total of 62 patients, eight (12.9\%) patients had evident fatigue (FSS $>5), 7$ (11.3\%) patients had fatigue limit values ( $\mathrm{FSS}=4.1-4.9)$ and $47(75.8 \%)$ patients had no fatigue $(\mathrm{FSS} \leq 4)$. The fatigue frequency was highly significant $(p<0.01)$, and almost three times higher in AITD patients compared to the control group, in which only 2 (3.8\%) subjects had evident fatigue. The Kruskal-Wallis test showed no significant difference in the concentration of TPOAbs between patients with and without fatigue (pTPOAb $=0.733$ ). There was no significant correlation between the concentration of TPOAbs and fatigue $(\mathrm{pFSS}=0.338$, Spearman coefficient $\mathrm{rFSS}=-0.124)$. The relationship between TPOAbs and fatigue in all 62 patients is shown in Figure 1.

The majority of the patients $(57 / 62,91.9 \%)$ had an increased concentration of $\mathrm{TgAb}$, with an average $\mathrm{TgAb}$ value of 679 (SD 936) IU/ml (minimal concentration $36 \mathrm{IU} /$ $\mathrm{ml}$, maximum $4112 \mathrm{IU} / \mathrm{ml}$ ). There was no significant correlation between the concentration of TgAbs and fatigue (pFSS $=0.773$, Spearman coefficient $r F S S=+0.037)$. The relationship between TgAbs and fatigue in all patients is shown in Figure 2.

\section{Fatigue and thyroid function}

The testing revealed that 49 (79\%) subjects had normal thyroid function, 5 (8.1\%) patients had subclinical hypothyroidism, 3 (4.8\%) patients had overt hypothyroidism, 2 (3.2\%) had subclinical hyperthyroidism and $3(4.8 \%)$ patients had overt hyperthyroidism (Table 1). Table 1 shows that the majority $(7 / 62,11.3 \%)$ of patients with fatigue at the time of testing had normal thyroid function, whereas only $1 / 62(1.6 \%)$ patients had overt hypothyroidism. When

Table 1. Fatigue and thyroid function in patients with AITD

\begin{tabular}{|c|c|c|c|c|}
\hline $\begin{array}{c}\text { Thyroid function/ } \\
\text { fatigue }\end{array}$ & $\begin{array}{c}\text { Without fatigue } \\
(\mathrm{FSS} \leq 4)\end{array}$ & $\begin{array}{c}\text { Fatigue limit values } \\
\text { (FSS }=4.1-4.9)\end{array}$ & $\begin{array}{c}\text { With fatigue } \\
(\mathrm{FSS} \geq 5)\end{array}$ & Total \\
\hline Euthyroidism & $36(58 \%)$ & $6(9.7 \%)$ & $7(11.3 \%)$ & $49(79 \%)$ \\
\hline $\begin{array}{c}\text { Subclinical } \\
\text { hypothyroidism }\end{array}$ & $5(8.1 \%)$ & 0 & 0 & $5(8.1 \%)$ \\
\hline $\begin{array}{c}\text { Overt } \\
\text { hypothyroidism }\end{array}$ & $1(1.6 \%)$ & $1(1.6 \%)$ & $1(1.6 \%)$ & $3(4.8 \%)$ \\
\hline $\begin{array}{c}\text { Subclinical } \\
\text { hyperthyroidism }\end{array}$ & $2(3.2 \%)$ & 0 & 0 & $2(3.2 \%)$ \\
\hline $\begin{array}{c}\text { Overt } \\
\text { hyperthyroidism }\end{array}$ & $3(4.8 \%)$ & 0 & 0 & $3(4.8 \%)$ \\
\hline Total & $47(75.8 \%)$ & $7(11.3 \%)$ & $8(12.9 \%)$ & $62(100 \%)$ \\
\hline
\end{tabular}


Table 2. Fatigue and depression in patients with AITD

\begin{tabular}{|c|c|c|c|c|}
\hline $\begin{array}{c}\text { Depression/ } \\
\text { Fatigue }\end{array}$ & $\begin{array}{c}\text { Without fatigue } \\
(\mathrm{FSS} \leq 4)\end{array}$ & $\begin{array}{c}\text { Fatigue limit values } \\
(\mathrm{FSS}=4.1-4.9)\end{array}$ & $\begin{array}{c}\text { With fatigue } \\
(\mathrm{FSS} \geq 5)\end{array}$ & Total \\
\hline With depression & $21(33.9 \%)$ & $3(4.8 \%)$ & $7(11.3 \%)$ & $31(50 \%)$ \\
\hline Without depression & $26(41.9 \%)$ & $4(6.5 \%)$ & $1(1.6 \%)$ & $31(50 \%)$ \\
\hline Total & $47(75.8 \%)$ & $7(11.3 \%)$ & $8(12.9 \%)$ & $62(100 \%)$ \\
\hline
\end{tabular}

the relationships of fatigue and the concentration of free thyroxine were analysed, a significant correlation was revealed between the degree of fatigue and the concentration of fT4 (pFSS $=0.040$, Spearman's coefficient $r=-0.261$ ), meaning that as the concentrations of fT4 increase the fatigue level decreases. However, the linear regression revealed that the strength of connections between fT4 and FSS was rather weak $(\mathrm{p}=0.047)$.

\section{Fatigue and depression}

Half of the AITD patients (31, 50\%) had depression $(B D I>9)$, where none of the subjects in the control group showed evidence of depression. Among the ATID patients, 7/62 (11.3\%) had fatigue and depression, whereas only one (1.6\%) had fatigue but no depression (this patient had normal thyroid function) (Table 2). There was a significant correlation between fatigue and depression among our AITD patients ( $\mathrm{p}=0.007$, Spearman's coefficient $\mathrm{r}=0.342$ ).

\section{DISCUSSION}

This study examined the frequency of fatigue in patients with AITD and analysed whether the occurrence of fatigue among these patients was correlated with the serum concentration of thyroid antibodies or thyroid function. To our knowledge, no such study has been performed until now.

We have shown that $8(12.9 \%)$ patients with AITD had fatigue, and this was almost three times the number of healthy control group subjects with fatigue. According to data reported in the literature, fatigue is a common problem with a prevalence that varies depending on the definition, duration, setting $(13,14)$, and study population. Therefore, fatigue is present in $6 \%$ of the control subjects without cancer, in comparison with more than $33 \%$ of patients with cancer (3). The frequency of fatigue among patients in primary care varies among studies; frequencies of $11.3 \%$ (4), $19 \%$ (15), or from $10 \%$ to $40 \%$ have been reported $(13,14)$. However, it should be noted that a portion of primary care patients have a disease that is accompanied by fatigue (e.g., systemic connective tissue diseases, anaemia, tumours, liver and kidney diseases, patients on psychoactive medication), and such patients were excluded from our study.

However, if the prevalence of fatigue in our patients with AITD is compared with data in the literature related to chronic inflammatory connective tissue diseases, then the fatigue among our patients is less frequent than that among patients with SLE, RA or primary Sjögren's syndrome. The prevalence of fatigue is as high as $81 \%$ in patients with systemic lupus erythematosus (7), $42 \%$ in patients with RA (6), 68\% in patients with Sjögren's syndrome (16) and $37 \%$ in patients with immune thrombocytopenic purpura (9). The majority of patients with multiple sclerosis (53-87\%) have fatigue (17).

In our study, we have shown that the occurrence and severity of fatigue does not depend on the concentration of TPOAbs or on the concentration of TgAbs. Although multiple mechanisms are involved in the damage of the thyroid tissue in AITD, especially cellular immunity (18-20), high concentrations of thyroid antibodies in the serum of patients with AITD indicate the activity of the autoimmune process (19). Therefore, the fatigue in our patients with AITD is not correlated with disease activity. Similar results have been obtained in the majority of studies related to fatigue in autoimmune diseases. The relationship between fatigue and activity of SLE is controversial (21-23), while fatigue in RA was related to pain and functioning but not inflammation (6). Given that patients with AITD have not expressed incapacitating clinical symptoms, especially if the thyroid function is unchanged, then a similar mechanism cannot be a cause of fatigue in our patients.

Thyroid dysfunctions may be accompanied by numerous neurological $(24,25)$ and psychiatric disorders $(26,27)$, the most well-known being cognitive impairment and depression in hypothyroid patients $(28,29)$. Considering that the majority of subjects with fatigue in our study had normal thyroid function, we could preliminarily conclude that hypothyroidism alone cannot account for the fatigue in our study. When we tested the relationship between fatigue and the concentration of free thyroxine, we found that there was a statistically significant correlation between the degree of fatigue in our patients and the concentration of fT4; therefore, the fatigue level decreased as the concentration of fT4 increased. However, the strength of the correlation between fT4 and FSS is weak ( $\mathrm{p}=0.047)$. Regardless of this result, hypothyroidism is less likely an aetiology of fatigue in our AITD patients. A similar finding was reported in a recently published study of Louwerens et al. (30), in which autoimmune hypothyroid patients had significantly higher levels of fatigue compared to the patients with differentiated thyroid carcinoma, but it could not be attributed to clinical or thyroid hormone parameters.

There are numerous reports in the literature on the associated occurrence of depression and $\operatorname{AITD}(29,31)$. Giv- 
en that depression may affect the measurement of fatigue as a confounding factor (2), we examined the frequency of depression in patients with AITD, as well as in the healthy control group. In addition, we analysed whether the occurrence of fatigue and depression was associated. We showed that $50 \%$ of patients had depression, whereas $11.3 \%$ patients had fatigue and depression; only one (1.6\%) patient had fatigue but no depression. In the control euthyroid group, none of the subjects had depression, although two subjects had evident fatigue. There was a significant correlation between fatigue and depression in our AITD patients. While a number of previously published studies found no association between fatigue and depression in patients with multiple sclerosis $(32,33)$, the majority of recently published studies found that depression had a significant impact on the occurrence of fatigue $(34,35)$. Although depression was more common than fatigue in our AITD patients, the positive correlation between the two variables indicates that the occurrence of fatigue and depression are associated. However, this does not necessarily mean that depression in our study is a confounding factor that affects the measurement of fatigue. The possibility that the fatigue and depression in AITD were caused by some other still insufficiently clarified mechanism cannot be excluded.

In conclusion, the frequency of fatigue was highly significant and almost three times higher in our AITD patients compared to the healthy subjects in the control group. The majority of patients with fatigue had normal thyroid function. We did not find significant correlations between fatigue and the concentrations of thyroid antibodies. There was a statistically significant correlation between fatigue and depression in our AITD patients.

\section{Acknowledgments}

This work was supported by the Ministry of Science, Republic of Serbia (grant numbers 175069, 41010).

\section{REFERENCES}

1. Krupp LB, Pollina DA. Mechanisms and management of fatigue in progressive neurological disorders. Curr Opin Neurol 1996; 9: 458-60.

2. Northeim KB, Jonssopn G, Omdal R. Biological mechanisms of chronic fatigue. Rheumatology (Oxf) 2011; 50: 1009-18.

3. Stone P, Richards M, A'Hern R, Hardy J. A study to investigate the prevalence, severity and correlates of fatigue among patients with cancer in comparison with a control group of volunteers without cancer. Ann Oncol 2000; 11: 561-7.

4. Wessely S, Chalder T, Hirsch S, Wallace P, Wright D. The prevalence and morbidity of chronic fatigue and chronic fatigue syndrome: a prospective primary care study. Am J Public Health 1997; 87: 1449-55.
5. Krupp LB, Alvarez LA, LaRocca NG, Scheinberg LC. Fatigue in multiple sclerosis. Arch Neurol 1988; 45:435-7.

6. Van Hoogmoed D, Fransen J, Bleijenberg G, van Riel P. Physical and psychosocial correlates of severe fatigue in rheumatoid arthritis. Rheumatology (Oxf) 2010; 49: 1294-302.

7. Tench CM, McCurdie I, White PD, D'Cruz DP. The prevalence and associations of fatigue in systemic lupus erythematosus. Rheumatology (Oxf)2000; 39: 1249-54.

8. Bjerrum K, Prause JU. Primary Sjogren's syndrome: a subjective description of the disease. Clin Exp Rheumatol 1990; 8:283-8.

9. Reese JA, Newton J, Watson S, et al. Documentation of fatigue in patients with immune thrombocytopenic purpura (ITP) and its association with autonomic dysfunction. Blood (ASH Annual Meeting Abstracts) 2010; 116: 570.

10. Krupp LB, LaRocca NG, Muir-Nash J, Steinberg AD. The fatigue Severity Scale. Arch Neurol 1989; 46: 1121-3.

11. Bakshi R, Shaikh ZA, Miletich RS, et al. Fatigue in multiple sclerosis and its relationship to depression and neurological disability. Mult Scler 2000; 6:181-5.

12. Beck AT, Ward CH, Mendelson M, Mock J, Erbaugh J. An inventory for measuring depression. Arch Gen Psych 1961; 4: 561-71.

13. Kroenke K, Wood D, Mangelsdorff D, Meier N, Powell J. Chronic fatigue in primary care: prevalence, patient characteristics and outcome. JAMA 1988; 260: 929-34.

14. David A, Pelosi A, McDonald E, et al. Tired, weak or in need of rest: fatigue among general practice attenders. BMJ 1990; 301:1199-222.

15. Buchwald D, Umali P, Umali J, Kith P, Pearlman T, Komaroff AL. Chronic fatigue and the chronic fatigue syndrome: prevalence in a Pacific northwest health care system. Ann Int Med 1995; 123: 81-8.

16. Giles I, Isenberg D. Fatigue in primary Sjögren's syndrome: Is there a link with the fibromyalgia syndrome? Ann Rheum Dis 2000; 59: 875-8.

17. Strober LB, Arnett PA. An examination of four models predicting fatigue in multiple sclerosis. Arch Clin Neuropsychol 2005; 20: 631-46.

18. Zivancevic-Simonovic S, Djukic A, Arsenijevic $\mathrm{N}$, Dimitrijevic Lj. Autoimunska bolest štitaste žlezde:patogeneza Gravesove bolesti i Hashimoto tireoiditisa. Medicus 2003; 4: 21-6.

19. Sinclair D. Clinical and laboratory aspects of thyroid autoantibodies. Ann Clin Biochem 2006; 43: 173-83.

20. McLachlan SM, Nagayama Y, Pichurin PN, et al. The link between Graves' disease and Hashimoto's thyroiditis: A role for regulatory T cells. Endocrinology 2007; 148: 5724-33.

21. Zonana-Nacach A, Roseman JM, McGwin G Jr, et al. Systemic lupus erythematosus in three ethnic groups. VI: Factors associated with fatigue within 5 years of criteria diagnosis. Lupus 2000; 9:101-9. 
22. Wang B, Gladman DD, Urowitz MB. Fatigue in lupus is not correlated with disease activity. J Rheumatol 1998; 25: 892-5.

23. Bruce IN, Mak VC, Hallett DC, Gladman DD, Urowitz M. Factors associated with fatigue in patients with systemic lupus erythematosus. Ann Rheum Dis 1999; 58: 379-81.

24. Farracci F, Carnevale A. The neurological disorder associated with thyroid autoimmunity. J Neurol 2006; 253: 975-84.

25. Miletic-Drakulic S, Toncev G, Vrndic O, Zivancevic-Simonovic $S$. Neurological symptoms and signs in patients with autoimmune thyroid disease. Serbian Journal of Experimental and Clinical Research 2011; 12: 123-6.

26. Hall RCW, Popkin MK, DeVaul R. Psychiatric manifestations of Hashimoto's thyroiditis. Psychosom 1982; 23: 337-42.

27. Kramer CK, von Mühlen D, Kritz-Silverstein D, BarrettConnor E. Treated hypothyroidism, cognitive function, and depressed mood in old age: the Rancho Bernardo Study. Eur J Endocrinol 2009; 161: 917-21.

28. Dugbartey AT. Neurocognitive aspects of hypothyroidism. Arch Intern Med 1998; 158: 1413-8.

29. Jorde R, Waterloo K, Storhaug H, Nyrnes A, Sundsfjord J, Jenssen TG. Neuropsychological function and symptoms in subjects with subclinical hypothyroidism and the effect of thyroxine treatment. J Clin Endocrinol Metab 2006; 91: 145-53.

30. Louwerens M, Appelhof BC, Verloop H, et al. Fatigue and fatigue-related symptoms in patients treated for different causes of hypothyroidism. Eur J Endocrinol 2012; 167(6): 809-15.

31. Pop VJ, Maartens LH, Leusink G, et al. Are autoimmune thyroid dysfunction and depression related? J Clin Endocrinol Metab 1998; 83: 3194-7.

32. Vercoulen JH, Hommes OR, Swanink CM, et al. The measurement of fatigue in patients with multiple sclerosis. A multidimensional comparison with chronic fatigue syndrome and healthy subject. Arch Neurol 1996; 53:642-9.

33. Möller A, Weidemann G, Rohde U, Backmund H, Sonntag A. Correlates of cognitive impairment anddepressive mood disorder in multiple sclerosis. Acta Psychiatr Scand 1994; 89: 117-21.

34. Koroecke DC, Lynch SG, Denney DR. Fatigue in multiple sclerosis: relationship to depression, disability and disease pattern. Mult Scler 2000; 6:131-6.

35. Iriarte J, Subira ML, Castro P. Modalities of fatigue in multiple sclerosis: correlation with clinical and biological factors. Mult Scler 2000; 6: 124-30. 